\title{
3. Pacificness - telling our own side of the story
}

\section{ABSIRACI}

Pasifika people face increased marginalisation if they do not become active participants in any media discourse. Newer, portable technologies open opportunities for smaller societies to become part of the media landscape. There are now more opportunities for smaller voices to express their Pasificness and be heard over the din of the mainstream. As a community, this commentary argues, Pacific people must make sure their side of the story is told in the digital era.

\section{SANDRA KAILAHI}

Television New Zealand journalist

\begin{abstract}
A PRESS release in mid-May 2008 headed, 'Polynesian immigration fuels underclass', by Massey University economist Dr Greg 1 Clydesdale, prompted the Dominion Post to report his controversial and negative claims about Pacific Islands migrants (see de Bres, pp. 149-167). The press release and subsequent stories sparked a national controversy and international attention. It is unlikely that it would have done so if the newspaper had not run the story as its front page lead. In a personal communication to the Race Relations Commissioner in response to a draft of this report, the editor of the Dominion Post, Tim Pankhurst, commented:
\end{abstract}

We did not wish to create offence and have good relations with the Pacific community. They feature regularly in our newspaper, most often in positive ways, something Pacific Affairs Minister Winnie Laban has commented on. (Cited in Kailahi, 2008)

Would he have really made this comment if there wasn't the uproar, not only from Pacific people but mainstream New Zealanders? The Clydesdale report shows that there is still a need for a strong Pasifika media. We know mainstream media sensationalised the story with its headline, 'Pacific 
migrants 'drain on economy', but it took the Pasifika media to clarify the issue and dig deeper to challenge the statements being made and set the record straight with in-depth discussions and perspectives on programmes such as Television New Zealand's Tagata Pasifika and Niu FM.

Mainstream media need to learn more about how Pacific people function so they don't have the kind of knee-jerk reaction to the stories like the Clydesdale one. But where do we go from here? Forward and just keep going like we always have. Pacific people have made great strides since arriving here in big numbers in the 1950s and the 1960s. They have reached great heights in New Zealand society and continue to punch well above their weight, particularly in the area of the country's national sport, rugby union. Five Members of Parliament are of Pacific Islands extraction, as are two district court judges.

At the same time however, Pacific people are over-represented in alarming social statistics, particularly in health and in law and order. Mean average incomes remain low and education achievement levels remain below the national average. These are all issues that are regularly portrayed in the media, often with negative connotations, except when it comes to, perhaps, sport and music.

In the 1970s, the media focused on Pacific Islanders in the so-called 'Dawn Raids $^{1}$, , so, we have been in the media spotlight for decades. But given the contribution Pacific people make to New Zealand society, the numbers in the media providing that all-important balanced or different viewpoint is miniscule. This has to be a concern for the Pacific and wider community.

In order for us to move forward, we need to be realistic about our capabilities so I would like to give an overview of what the current state of play is with Pacific and mainstream media and where we go from here.

The major Pacific media news organisations in New Zealand:

\section{Television:}

TVNZ: Tagata Pasifika (21 years); TVONE News Pacific team (5 years) Triangle TV:

- Tongan programme - TNews; Injoy Productions Setita Miller

- Samoan programme - Kilakokonuts

TV3 (Pacific Beat Street)

Regional TV (Samoan programme in Christchurch) 


\section{Radio}

Niu FM (National FM radio network)

Radio 531pi (Auckland Pan Pacific radio)

Radio Samoa (Auckland Samoa)

Samoa Capital radio (Wellington)

Samoa Access radio (Christchurch)

\section{Newspapers}

\section{Samoa}

Samoa Post

Samoa Times (Radio Samoa)

Samoan Observer

\section{Tonga}

Kele'a

Taimi 'o Tonga

Tonga Taina - independent (Former Taimi journalist Kite Tu'akalau)

Talaki (former editor of Taimi, Filo Akau'ola); Auckland

\section{Others:}

Niue Star (status uncertain); Fiji Observer (suspended)

\section{Online media}

Event Polynesia

Other newspapers (Planet-Tonga, Observer, Samoa Times etc)

\section{Casualties:}

Samoana; Cook Islands newspapers and upheavals witnessed with the Pasifika national radio network

We know that Pacific people make up more than seven percent $(265,975)$ of the total New Zealand population of 4,027,947 (Statistics NZ, 2006) here yet our representation in mainstream media reporting would probably be 10 times that figure. Why is that? According to the New Zealand Journalism Training Organisation national journalists survey of 2006, Pacific journalists make up two percent of all journalists in the country and Pacific journalism students account for two percent of all journalism students. There is simply not enough of us in crucial areas. 
Two percent? The line-up includes Barbara Dreaver and Tapu Misa-two well-known mainstream journalists but even more importantly-they are high profile Pacific journalists. Two so far. Well, I could add myself to the list as a former TVNZ Fair Go consumer affairs investigative programme and now TVNZ 7 producer/reporter as well as Phil Mcgrath who works alongside me. So that makes four. Richard Pamatatau, Radio New Zealand's Pacific correspondent, takes it up to five. Less well known are OneNews producer Tati Urale; OneNews reporter Shaleen Hern and new reporter and former Tagata Pasifika reporter, Adrian Stevanon, who scored a recent exclusive interview with Fiji's military leader Commodore Voreqe Bainimarama.

Eight so far. I can't overlook the talented and well regarded Niva Retimanu from Newstalk ZB. Nine. Then there is Leilani Moimoisea from Radio New Zealand as well as Sara Vui Talitu. From Radio New Zealand International, Moera Tuilaepa, and from Sport, the well-known Elma Ma'ua. Thirteen in the mainstream media that we know of - probably the most we've ever had in the past 30 years but we are still moving slowly towards changing mainstream perceptions of Pacific people.

In Pacific media, there are the likes of John Utanga, Osone Okesene, Lisa Taouma, Marama Papau and Aaron Taouma at Tagata Pasifika; from Niu FM: Iulia Leilua, Ruci Farrell and previous news editors Lito Vilisoni and Vienna Richards - a total of 10 and Irene Crawford Kaleopa who runs the radio show Te Putake. Roughly, a total of about 23.

This is not enough. In his article in Pacific Journalism Review entitled 'Pasifika media in the digital era', John Utanga (2007) said there was a distinct lack in the number of trained Pacific Islands journalists in New Zealand. Despite the many opportunities which exist here for formal journalism qualifications, the fact is too few Pacific people choose to go down that path.

In terms of job status, it is certainly not perceived as having the kind of prestige that a career in medicine or law seems to have among Pacific people. There are other reasons of course, both cultural and economic. However, at the 2006 Pacific Islands Media Association (PIMA) conference, veteran Pacific journalist and broadcaster Sefita Hao'uli remarked that journalism just had a too-hard tag and that many Pacific Islands students preferred to divert their energies into other parts of the media. There is a grain of truth in that, particularly when you see the numbers of Pacific 
people thriving in the creative arts but not in writing. Whether you agree with Hao'uli or not, it is obvious that some serious thought needs to be given to entice Pacific people into journalism. The evidence is only anecdotal, but having been in the industry for more than a decade and a half and seeing the few who have gone on to make a career out of it, it is certainly a concern.

This is one of the reasons that I helped set up the Pacific Islands Media Association (PIMA) along with Iulia Leilua and John Utanga in 2001. It was established to help Pacific people wanting to get into the media and to help those already in the media. Initially, we wanted to only have journalists but the reality was there were not enough of us. So we had to open it up to all Pacific people working in the media. One of the first things PIMA did was to find ways in which to assist students who chose to study communications and to this end two annual scholarships were secured with the sponsorship of AUT University's School of Communication Studies. We at PIMA are certainly grateful for the scholarships but understand that there is still much to be done. The irony is this shortage in trained Pacific Islands journalists comes at a time when there is great demand for their services from the growing Pacific media and from the mainstream. NiuFM has struggled to fill its roster of journalists, print publishers are always on the lookout for that combination of good language skills and journalism training. Many of the Pacific journalists still working in the industry today graduated from the Manukau Polytechnic Pacific Islands journalism course which ran from the end of the 1980s until 1994. Adapted from the New Zealand Certificate in Journalism it recruited well (some students already had bachelor degrees) and gave graduates a vital leg-up into the industry. Since the demise of the course, the number of Pacific people coming through has reduced significantly but hopefully with the formation of a new graduate journalism diploma aimed specifically at Māori and Pacific Island people at AUT, those numbers will change. This programme is due to begin in March 2010. We are lucky that David Robie champions our cause at AUT and in fact he has been instrumental in keeping PIMA alive over the past few years.

So where does the Pasifika media industry go from here and what are the implications for Pasifika media? Pacific Islands media people publish and speak in their vernacular languages - this has implications for training:

- There is a lack of trained journalists in New Zealand with little sign that more are coming through. 
- Most smaller media have untrained staff, partly because of the language issues and partly because of attracting Pacific Islanders to journalism training.

- The newer generation do not have great language skills.

- There are opportunities in mainstream media but fewer people are taking up the opportunity to train. (With the Fairfax New Zealand internship scheme in 2006, out of 17 interns selected, one was a Pacific Islander.)

PIMA, with the help of AUT, is trying to attract Pacific Islands people into journalism with scholarships and other strategies.

\section{Conclusion}

The pressing issues for Pasifika media in New Zealand are the lack of sufficient numbers of trained journalists and enough people attracted to it; the lack of a say in the strategic directions of New Zealand media; the need to be represented in key social policy areas; and the prospect of further marginalisation.

Media has an important role in educating and creating understanding in our rapidly expanding multi-cultural society. The future face of our communities will be like my son-part-Tongan, Samoan and European, and even more diverse with Somalian or Asian or Muslim backgrounds too. The challenge is, how do we communicate with this new generation which relates to different ethnic groups?

Pasifika people face increased marginalisation if they do not become active participants in any media discourse. Newer, portable technologies open huge opportunities for smaller societies to become part of the media landscape ie: there are more opportunities for smaller voices to be heard over the din of the mainstream. As John Utanga says:

There was a time when the only reason a Pacific person made the news was as the protagonist in a crime story or under the torchlight of an immigration officer. We say to ourselves, thankfully those days are over. But the reality is Pacific people are always going to make the news, whatever the circumstances. We need to be able to educate the public about our values and hopes and desires so that New Zealand, as a society, gets a better appreciation of its neighbours. As a community, Pacific people must make sure their side of the story is told in 
the digital era or face further marginalisation in New Zealand. What better way is there than to tell our stories and provide our side of the debate? (Utanga, 2007, pp. 27-28).

\section{Note}

1. In 1974, dawn raids by New Zealand police and immigration officials began an alleged overstayers in the Pacific Islands community. Politicians blamed Pacific Islanders for overloading social services, and they shaped a negative stereotype of Pasifika people. The Polynesian Panthers emerged in the 1970s to support Pacific peoples in New Zealand and to inform them of their rights in the face of injustice.

\section{References}

Kailahi, S. (2008). Delivering for Pacific peoples in the media. Paper presented at the Human Rights Commission Diversity Forum, Auckland, 25 August 2008.

Statistics NZ (2006). Census. Retrieved on 20 April 2009, from www.stats.govt.nz/ census/

Utanga, J. (2007). Pasifika media in the digital era. Pacific Journalism Review, 13(1), 19-28.

Sandra Kailahi is a television presenter/reporter with Television New Zealand's digital channel TVNZ7 news team. She has previously worked as a reporter for TVNZ's Tagata Pasifika and Fair Go consumer affairs programmes. An earlier version of this article was presented at the Human Rights Commission National Diversity Forum in Auckland, 25 August 2008. Sandra.Kailahi@tvnz.co.nz 